\title{
Growth Parameters of Summer Bajra at Different Phenological Stages as Influenced by Irrigation
}

\author{
P. Ashok ${ }^{1 *}$, K.P. Vani ${ }^{1}$, K.B. Suneeta Devi ${ }^{2}$ and P. Surendra Babu ${ }^{3}$ \\ ${ }^{1}$ Department of Agronomy, College of Agriculture, PJTSAU, Hyderabad, Telangana, India \\ ${ }^{2}$ Department of Agronomy, College of Agriculture, Jagtial, PJTSAU, Telangana, India \\ ${ }^{3}$ Agronomy, AICRP on Micronutrients, Agriculture Research institute, PJTSAU, \\ Rajendranagar, Hyderabad, Telangana, India
}

*Corresponding author

\begin{tabular}{|c|c|}
\hline & A B S T R A C T \\
\hline & \multirow{8}{*}{ 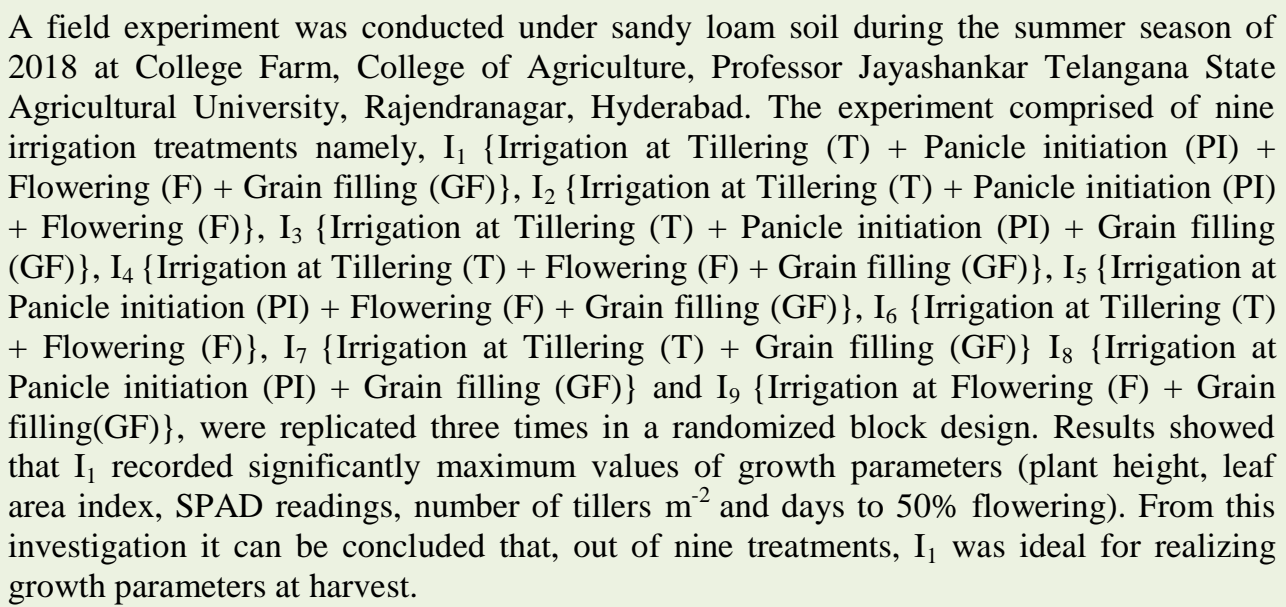 } \\
\hline & \\
\hline & \\
\hline & \\
\hline & \\
\hline Artic & \\
\hline & \\
\hline & \\
\hline
\end{tabular}

\section{Introduction}

Pearl millet (Pennisetum glaucum) is a species of the millet family also known as bulrush, spiked or cat-tail millet, it is the most drought tolerant cereal grown in the arid and semi-arid regions of the world. Globally, pearl millet is consumed in different forms: unleavened bread (roti or chapatti), porridge and gruel and hence it is often referred to as poorman's bread (Burton et al., 1972).India is the largest producer of pearl millet in the world occupying 7.129 million hectares with annual production of 8.067 million tonnes and average productivity of $1132 \mathrm{~kg} \mathrm{ha}^{-1}$ (Ministry of Agriculture and Farmers Welfare, Govt. of India, 2017). In Telangana it is grown on 0.05 lakh hectares with 0.04 lakh tonnes of production and productivity of $824 \mathrm{~kg} \mathrm{ha}^{-1}$ (Department of agriculture, Telangana, 2016- 
17). Pearl millet grain is more nutritious and the grain contains $11-19 \%$ protein, $60-78 \%$ carbohydrates and $3.0-4.6 \%$ fat and also has good amount of phosphorous and iron (Reddy et al., 2016). In addition to grain, pearl millet is also used as cattle feed, poultry feed and source of starch in the alcohol industry. Its fodder is an important source of animal feed particularly in dry months when alternative sources of feed are not available.

The productivity of pearl millet in India is very low as compared to important pearl millet growing countries in the world. It is, therefore, necessary to increase the production and productivity of pearl millet by adopting scientific innovations like proper water management technique for optimum crop production. Under water shortage conditions, water could be reserved for irrigation during the critical growth stages (Seghatoleslami et al., 2008). In kharif the pearl millet is cultivated under rainfed conditions with lowinput-low-output management, while summer pearl millet is cultivated under high-inputhigh-output management. Due to climate change, yield of kharif crop is adversely affected that's why area under summer pearl millet is increasing. High grain and fodder yield of better quality and greater water-use efficiency combined with tolerance to heat during flowering and grain development (air temperature during flowering can exceed $42^{\circ} \mathrm{C}$ ) are the reasons for cultivating pearl millet in the summer season (Upadhyay et al., 2001).

There is a need to explore opportunities to expand the area under summer pearl millet particularly in areas where irrigation is available and the fields are vacant during the summer season. Even though the adaptation of millet to the driest environments is realized, its vegetative response to water deficits has not been clearly described. Considering these facts in view, an irrigation experiment on summer pearl millet (Pennisetum glaucum L.) was planned to evaluate growth parameters.

\section{Materials and Methods}

Field experiment was carried out in sandy loam soil at College Farm, College of Agriculture, Professor Jayashankar Telangana State Agricultural University, Rajendranagar, Hyderabad. The $\mathrm{pH}$ of the experimental site was 7.8 , organic carbon was $0.63 \%$, available nitrogen, phosphorus and potassium were 175 $\mathrm{kg} \mathrm{ha}{ }^{-1}, 64 \mathrm{~kg} \mathrm{ha}^{-1}$ and $352 \mathrm{~kg} \mathrm{ha}^{-1}$ respectively.

The experiment comprised of nine irrigation treatments namely, I1 \{rrigation at Tillering $(\mathrm{T})+$ Panicle initiation $(\mathrm{PI})+$ Flowering $(\mathrm{F})+$ Grain filling $(\mathrm{GF})\}, \mathrm{I} 2$ \{rrigation at Tillering $(\mathrm{T})+$ Panicle initiation $(\mathrm{PI})+$ Flowering $(\mathrm{F})\}$, I3 \{Irrigation at Tillering $(\mathrm{T})+$ Panicle initiation (PI) + Grain filling (GF) \}, I4 $\{$ Irrigation at Tillering $(\mathrm{T})+$ Flowering $(\mathrm{F})+$ Grain filling (GF) \}, I5 \{rrigation at Panicle initiation $(\mathrm{PI})+$ Flowering $(\mathrm{F})+$ Grain filling (GF)\}, I6 \{Irrigation at Tillering (T) + Flowering (F)\}, I7 \{rrigation at Tillering (T) + Grain filling (GF) \} I8 \{Irrigation at Panicle initiation (PI) + Grain filling (GF) $\}$ and I9 \{Irrigation at Flowering $(\mathrm{F})+$ Grain filling $(\mathrm{GF})\}$, were replicated three times in a randomized block design. Pearl millet was sown on $19^{\text {th }}$ January, 2018 and harvested on $30^{\text {th }}$ April, 2018 During the growing season, the mean weekly maximum, minimum temperature, relative humidity, sunshine hour day $^{-1}$ and evaporation were $34.2^{\circ} \mathrm{C}, 16.2^{\circ} \mathrm{C}$, $78.4 \%, 25.5 \%, 8.36 \mathrm{hrs} \mathrm{dy}^{-1}$ and $5.46 \mathrm{~mm}$. Pearl millet was sown at a spacing of $45 \mathrm{~cm} \mathrm{x}$ $15 \mathrm{~cm}$ using seed rate of $4 \mathrm{~kg} \mathrm{ha}^{-1}$. The field was uniformly irrigated on the day of sowing. Further, one irrigation was given at 10 days after sowing. Further irrigations were given based on the treatments. $50 \mathrm{~mm}$ depth of irrigation water was applied at each irrigation. The RDF i.e. Nitrogen $\left(80 \mathrm{~kg} \mathrm{ha}^{-1}\right)$ was 
applied through urea in two equal splits, first as basal and the remaining dose at 30 DAS (days after sowing, whereas full dose of $\mathrm{P}_{2} \mathrm{O}_{5}$ $\left(40 \mathrm{~kg} \mathrm{ha}^{-1}\right)$ and full dose of $\mathrm{K}_{2} \mathrm{O}\left(30 \mathrm{~kg} \mathrm{ha}^{-1}\right)$ were applied through SSP and muriate of potash respectively, as basal dose to all the experimental plots.

Five plants were randomly selected in each net plot and tagged permanently. From these five plants growth parameters like plant height, SPAD readings and number of tillers were recorded. Leaf area is taken from the plants collected for dry matter production using LI 3000 portable area meter with transparent conveyor belt utilizing an electronic digital display. For all these growth parameters data was collected at different phenological stages i.e. tillering flowering grain filling and at harvest. Number of days taken from sowing to 50 per cent flowering was recorded in each treatment. By using the data of leaf area, LAI was calculated using following formula

$$
\text { LAI }=\frac{\text { Leaf area }\left(\mathrm{cm}^{2}\right)}{\text { Unit ground area }\left(\mathrm{cm}^{2}\right)}
$$

\section{Results and Discussion}

\section{Plant height (cm)}

It is apparent from the data (Table 1) that plant height significantly differed due to irrigations at all the stages of crop growth except at tillering stage. At flowering stage $\mathrm{I}_{1}$ treatment had significantly produced taller plants of $133.4 \mathrm{~cm}$ followed by $I_{2}(127.3 \mathrm{~cm})$ and $I_{3}$ $(125.1 \mathrm{~cm})$ which are on par with each other and significantly superior over other treatments.

At grain filling stage, the $I_{1}$ and $I_{2}$ had recorded maximum plant height of 152 and $149 \mathrm{~cm}$ and were on par with each other. Lowest value was observed in $\mathrm{I}_{9}$. At harvest
$\mathrm{I}_{1}$ recorded significantly highest plant height of $175 \mathrm{~cm}$ followed by $\mathrm{I}_{3}(164.5 \mathrm{~cm})$ and $\mathrm{I}_{4}(162.2$ $\mathrm{cm})$ though at par with each other and significantly superior over the rest of the treatments. While irrigation treatment, $\mathrm{I}_{9}$ $(116.9 \mathrm{~cm})$ recorded significantly the lowest plant height. Such a positive response might be due to increase in number of irrigations, which raised the moisture status of the soil and availability of soil moisture to the crop plant. These findings are in agreement with Vyas et al., (1992) and Sakellariou- Makrantonakiet al., (2007).

\section{Leaf area index}

Leaf area index revealed that it increased with advancement in growth stages till grain filling and gradually decreased towards harvest. Leaf area index had not differed significantly due to application of irrigations at tillering stage. Among the different nine irrigation levels, $I_{1}$, $\mathrm{I}_{2}$ and $\mathrm{I}_{3}$ recorded significantly higher leaf area index, $(3.45,3.4$ and 3.37) though at par with each other compared to the rest of the irrigation treatments at flowering stage. Similar trend of significantly higher LAI was observed at grain filling stage with $\mathrm{I}_{1}$ (3.95) and $I_{2}$ (3.89) followed $I_{3}(3.54)$ and $I_{4}(3.49)$ compared to the rest of the treatments.

At both the stages, i.e. at flowering (2.01) and grain filling (2.45) $\mathrm{I}_{9}$ recorded the lowest leaf area index. Leaf area index (LAI) is the main physiological determinant of the crop yield. at harvest stage $I_{1}$ had significantly produced more LAI of 2.75 followed by $\mathrm{I}_{3}(2.44)$ and $\mathrm{I}_{4}$ (2.42). Lowest LAI of 1.07 was recorded by $\mathrm{I}_{9}$ treatment. Increase in LAI under increased moisture availability and moisture supply contributed to more number of green leaves, size of leaves, etc., which led to higher leaf area and leaf area index. These results were in close proximity to those of Saren et al., (2004) (Table 2). 
Table.1 Growth parameters of summer pearl millet as influenced by irrigations at different phenological stages

\begin{tabular}{|c|c|c|c|c|c|c|c|c|c|c|c|c|}
\hline \multirow[t]{2}{*}{ Treatments } & \multicolumn{4}{|c|}{ Plant height (cm) } & \multicolumn{4}{|c|}{ Leaf area index } & \multicolumn{4}{|c|}{ SPAD readings } \\
\hline & $\mathbf{T}$ & $\mathbf{F}$ & GF & $\mathbf{H}$ & $\mathbf{T}$ & $\mathbf{F}$ & GF & $\mathbf{H}$ & $\mathbf{T}$ & $\mathbf{F}$ & GF & $\mathbf{H}$ \\
\hline $\mathbf{I}_{1}$ & 52.5 & $133.4 \mathrm{a}$ & $152 \mathrm{a}$ & $175 \mathrm{a}$ & 1.55 & $3.45 \mathrm{a}$ & $3.95 \mathrm{a}$ & $2.75 \mathrm{a}$ & 31.6 & $49.2 \mathrm{a}$ & $45.7 \mathrm{a}$ & $39.8 \mathrm{a}$ \\
\hline $\mathbf{I}_{2}$ & 49 & $127.3 \mathrm{a}$ & $149 \mathrm{a}$ & $151.4 \mathrm{c}$ & 1.50 & $3.40 \mathrm{a}$ & $3.89 \mathrm{a}$ & $2.11 \mathrm{c}$ & 29.2 & $48.9 \mathrm{a}$ & $43.5 \mathrm{a}$ & $33.2 \mathrm{c}$ \\
\hline $\mathbf{I}_{3}$ & 51.6 & $125.1 \mathrm{a}$ & $135.4 \mathrm{~b}$ & $164.5 \mathrm{~b}$ & 1.53 & $3.37 \mathrm{a}$ & $3.54 \mathrm{~b}$ & $2.44 b$ & 31.5 & $47.5 \mathrm{a}$ & $39.6 b$ & $37.1 \mathrm{~b}$ \\
\hline $\mathbf{I}_{4}$ & 51 & $115.4 \mathrm{~b}$ & $139 \mathrm{~b}$ & $162.2 \mathrm{~b}$ & 1.44 & $2.59 \mathrm{~b}$ & $3.49 \mathrm{~b}$ & $2.42 \mathrm{~b}$ & 30.3 & $42.9 \mathrm{~b}$ & $38.3 \mathrm{~b}$ & $36.3 \mathrm{~b}$ \\
\hline $\mathbf{I}_{5}$ & 45.3 & $103.3 \mathrm{c}$ & $122.1 \mathrm{c}$ & $129 \mathrm{e}$ & 1.52 & $2.33 \mathrm{c}$ & $3.14 \mathrm{c}$ & $1.47 \mathrm{e}$ & 28.0 & $38.0 \mathrm{c}$ & $34.2 \mathrm{c}$ & $26.0 \mathrm{e}$ \\
\hline$I_{6}$ & 46 & $114.6 \mathrm{~b}$ & $136.2 \mathrm{~b}$ & $141 \mathrm{~d}$ & 1.41 & $2.70 \mathrm{~b}$ & $3.57 \mathrm{~b}$ & $1.81 \mathrm{~d}$ & 29.6 & $42.3 \mathrm{~b}$ & $37.5 \mathrm{~b}$ & $30.1 \mathrm{~d}$ \\
\hline $\mathbf{I}_{7}$ & 44.4 & $115.1 \mathrm{~b}$ & $120.3 \mathrm{c}$ & $139.2 \mathrm{~d}$ & 1.42 & $2.69 \mathrm{~b}$ & $2.86 \mathrm{c}$ & $1.79 \mathrm{~d}$ & 28.8 & $41.1 \mathrm{~b}$ & $30.1 \mathrm{c}$ & $28.8 \mathrm{~d}$ \\
\hline $\mathbf{I}_{8}$ & 47 & $102.5 \mathrm{c}$ & $110.5 \mathrm{~d}$ & $118.8 \mathrm{f}$ & 1.37 & $2.32 \mathrm{c}$ & $2.53 \mathrm{~d}$ & $1.12 \mathrm{f}$ & 29.0 & $36.4 \mathrm{c}$ & $27.4 \mathrm{~d}$ & $23.3 \mathrm{f}$ \\
\hline$I_{9}$ & 48.1 & $87 \mathrm{~d}$ & $107.7 \mathrm{~d}$ & $116.9 \mathrm{f}$ & 1.38 & $2.01 \mathrm{~d}$ & $2.45 \mathrm{~d}$ & $1.07 \mathrm{f}$ & 28.5 & $33.5 \mathrm{~d}$ & $26.2 \mathrm{~d}$ & $21.4 \mathrm{f}$ \\
\hline Mean & 48.32 & 113.7 & 130.24 & 144.23 & 1.46 & 2.76 & 3.27 & 1.89 & 29.64 & 42.2 & 35.83 & 30.67 \\
\hline S. Em. +/- & 1.80 & 2.92 & 3.12 & 3.19 & 0.06 & 0.08 & 0.09 & 0.08 & 0.8 & 0.97 & 0.92 & 0.89 \\
\hline CD (5\%) & NS & 8.76 & 9.35 & 9.58 & NS & 0.25 & 0.27 & 0.24 & NS & 2.81 & 2.75 & 2.67 \\
\hline
\end{tabular}

Tillering, F - Flowering, GF - Grain filling, H - Harvest 
Table.2 Growth parameters of summer pearl millet as influenced by irrigations

\begin{tabular}{|l|c|c|c|c|c|}
\hline \multirow{2}{*}{ Treatments } & \multicolumn{4}{|c|}{ Number of tillers $\mathrm{m}^{-2}$} & $\begin{array}{c}\text { Days to } \\
50 \% \\
\text { flowering }\end{array}$ \\
\cline { 2 - 6 } & T & F & GF & H & \\
\hline $\mathbf{I}_{\mathbf{1}}$ & 39.7 & $57.3 \mathrm{a}$ & $52.2 \mathrm{a}$ & $46.5 \mathrm{a}$ & $50 \mathrm{a}$ \\
\hline $\mathbf{I}_{\mathbf{2}}$ & 37.2 & $56.8 \mathrm{a}$ & $51.7 \mathrm{a}$ & $39.6 \mathrm{c}$ & $49 \mathrm{a}$ \\
\hline $\mathbf{I}_{\mathbf{3}}$ & 38.8 & $56.1 \mathrm{a}$ & $48.3 \mathrm{~b}$ & $43.1 \mathrm{~b}$ & $51 \mathrm{a}$ \\
\hline $\mathbf{I}_{\mathbf{4}}$ & 36.0 & $52.0 \mathrm{~b}$ & $46.2 \mathrm{~b}$ & $42.8 \mathrm{~b}$ & $55 \mathrm{~b}$ \\
\hline $\mathbf{I}_{5}$ & 37.0 & $46.8 \mathrm{c}$ & $37.8 \mathrm{c}$ & $32.1 \mathrm{e}$ & $62 \mathrm{c}$ \\
\hline $\mathbf{I}_{\mathbf{6}}$ & 36.7 & $51.8 \mathrm{~b}$ & $45.5 \mathrm{~b}$ & $36.4 \mathrm{~d}$ & $56 \mathrm{~b}$ \\
\hline $\mathbf{I}_{\mathbf{7}}$ & 35.6 & $50.9 \mathrm{~b}$ & $40.1 \mathrm{c}$ & $35.8 \mathrm{~d}$ & $57 \mathrm{~b}$ \\
\hline $\mathbf{I}_{\mathbf{8}}$ & 37.0 & $45.5 \mathrm{c}$ & $28.5 \mathrm{~d}$ & $25.3 \mathrm{f}$ & $60 \mathrm{c}$ \\
\hline $\mathbf{I}_{\mathbf{9}}$ & 34.7 & $40.8 \mathrm{~d}$ & $26.8 \mathrm{~d}$ & $23.9 \mathrm{f}$ & $69 \mathrm{~d}$ \\
\hline Mean & 37.0 & 50.9 & 41.9 & 36.2 & 56.56 \\
\hline S. Em. +/- & 0.97 & 1.22 & 1.03 & 0.92 & 0.86 \\
\hline CD (5\%) & NS & 3.68 & 3.08 & 2.77 & 2.58 \\
\hline
\end{tabular}

$\mathrm{T}$ - Tillering, F - Flowering, GF - Grain filling, H - Harvest

\section{SPAD readings}

SPAD readings at tillering stage were found to be statistically insignificant. However, at flowering stage, the significantly higher SPAD values (49.2) were recorded under $\mathrm{I}_{1}$ treatmentand was followed by $\mathrm{I}_{2}(48.9)$ and $\mathrm{I}_{3}(47.5)$, while the lowest SPAD values of 33.5 was noticed by $\mathrm{I}_{9}$. At grain filling stage, the SPAD values started declining and among the nine treatments, $I_{1}$ treatment recorded the significantly higher value of 45.7 which was followed by $\mathrm{I}_{2}$ (43.5) and lowest SPAD values of 27.4 were recorded by $\mathrm{I}_{9}$. At harvest stage SPAD values declined compared to the previous growth stages. 39.8 value of SPAD was noticed with $\mathrm{I}_{1}$ treatment which was significantly superior to $\mathrm{I}_{3}$ (37.1) and $\mathrm{I}_{4}(36.3)$ though on par superseding $I_{2}$ (33.2). The lowest SPAD values were shown by $\mathrm{I}_{9}$ and $\mathrm{I}_{8}$ which were statistically at par with each other (21.4 and 23.3). Significantly higher values of SPAD may be attributed to better root growth, resulting in higher water and nutrient uptake which resulted in increased chlorophyll content in leaves. Gonzalez et al., (2009) reported total chlorophyll was higher under irrigation scheduled at two-day interval compared to continuous drought and water stress.

\section{Number of tillers $\mathbf{m}^{-2}$}

Non-significant variation in number of tillers $\mathrm{m}^{-2}$ was observed due to effect of nine irrigation treatments at tillering stage. However, $I_{1}$ treatment recorded maximum number of tillers $\mathrm{m}^{-2}$ (57.3) followed by $\mathrm{I}_{2}$ and 
$\mathrm{I}_{3}$ with 56.8 and 56.1 tiller number which were at par with each other. Lowest number of tillers $\mathrm{m}^{-2}$ was observed with $\mathrm{I}_{9}$ treatment (40.8). At grain filling stage, significantly maximum number of shoots were noticed with $I_{1}(52.2)$ and $I_{2}(51.7)$ and were followed by $I_{3}$ (48.3), $I_{4}$ (46.2) and $I_{6}$ (Irrigation at Tillering + Flowering) (45.5) which were statistically at par but differed significantly with the rest of the treatments. Minimum number of tillers $\mathrm{m}^{-2}$ were recorded with $\mathrm{I}_{9}$ treatment (26.8). At harvest stage $\mathrm{I}_{1}$ treatment significantly recorded higher number of tillers (46.5) followed by $\mathrm{I}_{3}$ (43.1) and $\mathrm{I}_{4}(42.8)$ which were significantly superior over other treatments, while $\mathrm{I}_{9}$ treatment (23.9) produced the lowest number of tillers. The higher number of tillers might be due to enhanced cell expansion and various metabolic processes in the presence of abundant supply of moisture which resulted into increased tillering. The results confirms the findings of Singh et al., (2012).

\section{Days to $50 \%$ flowering}

Days to $50 \%$ flowering was significantly influenced by Irrigation at tillering and panicle initiation. The irrigation treatments $\mathrm{I}_{1}$ (50), $I_{2}$ (49) and $I_{3}(51)$ taken significantly lower number of days to $50 \%$ flowering followed by $\mathrm{I}_{4}(55)$ and it was on par with $\mathrm{I}_{6}$ (56) and $I_{7}$ (57). Significantly longer period was taken by the crop for $50 \%$ flowering in $\mathrm{I}_{9}$ with 69 days. The crop has taken more number of days for $50 \%$ flowering where the irrigation was skipped at tillering and panicle initiation stage. It is due to moisture stress at early stages caused poor development of crop. These findings are in accordance with Fukai et al., (1994).

\section{References}

Burton, G.W., Wallace, A.T and Rachie, K.O. 1972. Chemical composition and nutritive value of pearl millet [Pennisetum typhoides (burm.) stapfand E. C. Hubbard] grain. Crop Science. 12: 187-188.

Department of Agriculture, Telangana, 201617.

Fukai, S and Lilley, J.M. 1994. Effects of timing and severity of water deficit on four diverse rice cultivars. phenological dev, crop growth and grain yield. Field Crops Research. 37: 225-234.

Gonzalez, J.A., Gallardo, M., Hilal, M., Rosa, M., and Prado, F.E. 2009. Physiological responses of quinoa (Chenopodium quinoa Willd.) to drought and waterlogging stresses, dry matter partitioning. Botanical Studies. 50: $35-42$.

Ministry of Agriculture and Farmers Welfare, Govt. of India, 2017.

Reddy, S.B.P., Naga madhuri, K.V., Keerthi Venkaiah and Prathima, T. 2016. Effect of nitrogen and potassium on yield and quality of pearl millet (Pennisetum glaucum L.) International Journal of Agriculture Innovations and Research. 4(4): 678681.

Sakellariou-Makrntonaki, M., Papalexis, D., Nakos, $\mathrm{N}$ and Kalavrouziotis, I.K. 2007. Effect of modern irrigation methods on growth and energy production of sweet sorghum (var. Keller) on adry year in Central Greece. Agricultural Water Management. 90: 181-189.

Saren, B.K., Dey, S and Mandel, D. 2004. Effect of irrigation and sulphur on yield attributes, productivity, consumptive use, consumptive use efficiency of wheat (Trtitcum aestivum). Indian Journal of Agricultural Sciences. 74(5): 257-261.

Seghatoleslami, M.J. Kafi, M and Majidi, E. 2008. Effect of deficit irrigation on 
yield, WUE and some morphological and phenological traits of three millet species.

Singh, L., Singh, C.M and Singh, G.R. 2012. Response of bed planted wheat (Tritcum aestivum L.) under different moisture regimes on water use and its efficiency. Journal of Chemical and Pharmaceutical Research. 4(11): 4941-4945.

Upadhyay, P.N., Dixit, A.G., Patel, J.R and Chavda, J.R. 2001. Response of summer pearl millet (Pennisetum glaucum) to time and method of planting, age of seedling and phosphorous grown on loamy sand soils of Gujarat. Indian Journal of Agronomy. 46 (1): 126-130.

Vyas, S.H., Patel, J.C., Patel, B.S. and Sukhadia, N. 1992. Response of summer pearl millet (Pennisetum glaucum) to irrigation nitrogen and phosphorus. Indian Journal of Agronomy. 37 (4): 819-821.

\section{How to cite this article:}

Ashok, P., K.P. Vani, K.B. Suneeta Devi and P. Surendra Babu. 2018. Growth Parameters of Summer Bajra at Different Phenological Stages as Influenced by Irrigation. Int.J.Curr.Microbiol.App.Sci. 7(07): 2923-2929. doi: https://doi.org/10.20546/ijcmas.2018.707.342 